\title{
Sistem Informasi Persediaan Barang dan Penjualan pada Bengkel Matahari Motor
}

\author{
Hendro \\ ${ }^{1}$ Program Studi Sistem Informasi, Universitas Widya Dharma Pontianak \\ *hendro@widyadharma.ac.id
}

\begin{abstract}
Computer technology can be applied to improve a company's business performance, including inventory management, purchasing, and sales process, and report making process. Bengkel Matahari Motor still uses a manual system in inventory and sales systems. The number of daily transactions and the types of goods sold requires better inventory management. The decision making is also slow due to the inaccurate data. The objective of this research is to design a computerized system that can solve existing problems to improve company performance, especially in data storage and access. The writer uses the prototyping model as the software development method and observation, interview, literature study as data collection methods. The writer uses Unified Modeling Language (UML) as the data analysis technique for the system. The final result of this research is the computerized system has the ability to process data more accurately and quickly. A computerized inventory system can produce information more quickly and accurately so that it can support a better decision-making process. A Computerized sales system can improve the quality of service to buyers and increase sales. The advice given to optimize system performance is the company should provide training to employees whowho operate the system so that the system can be used well and smoothly.
\end{abstract}

Keywords: information systems, inventory, computerization

\begin{abstract}
Abstrak
Teknologi komputer dapat dimanfaatkan untuk meningkatkan kinerja bisnis suatu perusahaan antara lain manajemen persediaan, pembelian, penjualan dan pembuatan laporan. Bengkel Matahari Motor masih menggunakan sistem manual dalam sistem persediaan dan penjualan. Jumlah transaksi harian dan jenis barang yang dijual cukup banyak memerlukan sebuah manajemen persediaan barang yang lebih baik. Proses pengambilan keputusan juga lambat karena kurang akuratnya data. Tujuan penelitian penulis adalah merancang sebuah sistem terkomputerisasi sehingga dapat mengatasi permasalahan yang ada sehingga dapat meningkatkan kinerja perusahaan terutama dalam masalah penyimpanan dan pengaksesan data. Penulis menggunakan prototyping model sebagai metode pengembangan software, dan metode observasi, wawancara dan studi kepustakaan sebagai metode pengumpulan data. Penulis menggunakan Unified Modeling Language (UML) sebagai teknik analisis data dalam sistem informasi persediaan dan penjualan. Adapun hasil akhir dari penelitian ini adalah sistem terkomputeriasi memiliki kemampuan untuk mengolah data lebih akurat dan cepat dibandingkan secara manual. Sistem persediaan yang terkomputerisasi mampu menghasilkan informasi yang lebih cepat dan akurat sehingga dapat menunjang proses pengambilan keputusan secara lebih baik. Sistem penjualan yang terkomputerisasi dapat meningkatkan kinerja pelayanan kepada pembeli dan dapat meningkatkan penjualan. Saran yang diberikan untuk mengoptimalkan kinerja sistem adalah perusahaan disarankan untuk memberikan pelatihan kepada karyawan yang terlibat dalam proses pengoperasian sistem supaya sistem yang digunakan pada berjalan dengan baik dan lancar.
\end{abstract}

Kata kunci: sistem informasi, persediaan barang, komputerisasi

\section{Pendahuluan}

Perkembangan industri bisnis yang dipicu oleh pengaruh modernisasi membuat pemilik usaha di Indonesia perlu melakukan otomatisasi kantor pada perusahaan yang dijalankan. Otomatisasi kantor atau usaha dinilai merupakan cara yang inovatif dalam membantu perusahaan untuk mewujudkan 
prosedur kerja yang cepat, efektif serta memiliki manfaat jangka panjang. Salah satu keuntungan penerapaan otomatisasi kantor adalah adanya manejemen persediaan.

Manajemen persediaan (inventory control) merupakan kegiatan yang berkaitan dengan perencanaan dan pengawasan kebutuhan material sehingga di satu pihak kebutuhan operasi dapat dipenuhi pada waktunya dan di lain pihak investasi persediaan material dapat ditekan secara optimal [1]. Sistem informasi yang terintegrasi sangat penting untuk menyediakan informasi yang bersifat real time bagi pihak manajemen dan menciptakan koordinasi yang baik antar departemen. Penerapan sistem informasi juga harus didukung dengan sumber daya manusia yang kompeten [2].

Dalam melakukan kegiatan operasionalnya, Bengkel Matahari Motor masih menggunakan prosedur konvensional. Contohnya ketika pelanggan meminta jasa service atau membeli suku cadang, pihak bengkel tidak mendokumentasikannya dalam bentuk apapun dan ketika pihak bengkel ingin memesan suku cadang dari supplier, pihak bengkel hanya menyimpan salinan bukti pesanan pembelian yang didapatkan dari supplier. Prosedur usaha seperti ini dinilai tidak efektif terutama bagi usaha yang mulai berkembang karena akan menghambat produktivitas usaha dan terjadinya kesulitan pengambilan keputusan oleh pihak bengkel akibat data yang sulit diperoleh.

Penerapan otomatisasi kantor pada Bengkel Matahari Motor adalah menciptakan sistem kerja yang terstruktur untuk mengatasi beberapa masalah yang terdapat pada Bengkel Matahari Motor seperti kurangnya track record akan kegiatan penjualan dan pembelian di satu periode serta pelayanan kepada pelanggan yang tidak sistematis. Contoh masalah tersebut dapat menimbulkan kesulitan pada pengambilan keputusan perusahaan dan menghambat produktivitas usaha. Otomatisasi kantor pada Bengkel Matahari Motor akan meningkatkan produktivitas bengkel dengan menciptakan prosedur kerja yang sistematis dengan bantuan teknologi informasi sehingga pekerjaan menjadi lebih efisien dan kesalahan akibat human error bisa diminimalisir.

\section{Metoda Penelitian}

\subsection{Observasi}

Metode ini dilakukan dengan pengamatan langsung terhadap sistem persediaan dan penjualan yang sedang berlangsung pada Bengkel Matahari Motor.

\subsection{Wawancara}

Metode ini dilakukan dengan mengadakan tanya jawab dengan karyawan dan pihak Bengkel Matahari Motor yang terlibat secara langsung dalam sistem persediaan dan penjualan barang untuk memperoleh informasi yang diperlukan dalam penelitian.

\subsection{Studi Kepustakaan}

Metode ini dilakukan oleh penulis dengan mencari dan mengumpulkan data yang diperlukan untuk penelitian ini. Data tersebut dapat berupa teori-teori maupun konsep-konsep yang berasal dari buku, karya ilmiah yang berkaitan dengan masalah penelitian.

\subsection{Teknik Analisa Data}

Teknik analisa data yang digunakan oleh penulis dalam menganalisis dan merancang sistem persediaan dan penjualan pada penelitian ini adalah permodelan Unified Modeling Language (UML). UML telah menjadi suatu standar industry untuk visualisai, perancangan dan dokumentasi suatu software. [3]

\subsection{Model Prototyping}

Metode pengembangan perangkat lunak yang digunakan pada penelitian ini adalah model prototyping. Prototyping adalah suatu model pengembangan perangkat lunak yang merupakan contoh versi awal dari sistem yang akan dibangun. Prototyping dimulai dengan identifikasi kebutuhan awal. Proses tersebut dilakukan untuk menentukan tujuan sistem, fungsi sistem, serta kebutuhan yang diinginkan. Selanjutnya pengembang sistem akan membuat suatu desain awal dan menciptakan sebuat prototype dari sistem tersebut. Selanjutnya user akan mencoba prototype tersebut, mengevaluasi sistem tersebut dan merekomendasikan perubahan yang diperlukan untuk memenuhi kebutuhan user. Perubahan prototype akan dilakukan 
sesuai rekomendasi dan selanjutnya akan diujikan kembali sampai pada akhirnya prototype tersebut diterima dan pembuatan produk sesungguhnya akan dilakukan. [4]

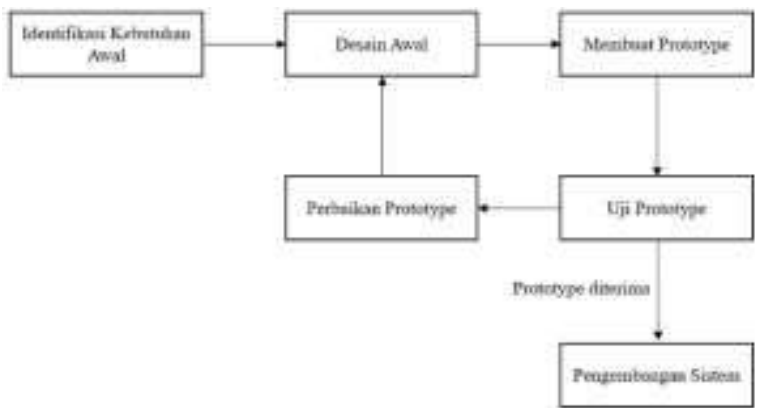

Gambar 1. Model Prototyping

\section{Hasil Penelitian}

\subsection{Permasalahan Sistem Berjalan}

Berdasarkan hasil

observasi, wawancara, dan studi kepustakaan, penulis menemukan beberapa permasalahan yang ada pada sistem berjalan, antara lain:

1. Pengolahan data bersifat manual, proses penjualan dan pembelian dicatat sehingga pengolahan data menjadi lambat.

2. Penyimpanan data masih berbentuk arsip sehingga menyulitkan proses pencarian data.

3. Pembuatan laporan lambat sehingga pengambilan keputusan juga menjadi lambat.

4. Pengelolaan stock barang belum terkontrol dengan baik.

\subsection{Permodelan Sistem Usulan}

Berdasarkan hasil analisa dan perancangan sistem menggunakan permodelan UML, maka sistem usulan digambarkan sebagai berikut:

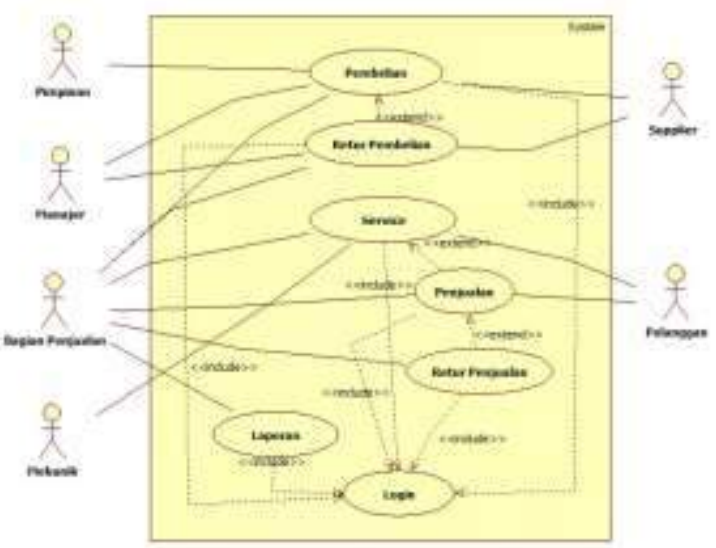

Gambar 2. Diagram Use Case Sistem Usulan
Sistem usulan akan melibatkan enam aktor yang saling berkaitan yaitu pimpinan, manajer, bagian penjualan, mekanik, supplier, dan pelanggan. Pimpinan bertugas untuk menyetujui pembelian, melakukan pembayaran, menerima laporan dan mengevaluasi laporan serta mengambil keputusan operasional di dalam perusahaan. Manajer bertugas memeriksa dan menyetujui pesanan barang ke supplier, menyetujui retur penjualan dan pembelian, serta memeriksa semua laporan transaksi yang dicetak oleh bagian penjualan. Bagian penjualan bertugas melayani pelanggan, memeriksa ketersediaan stok, serta membuat laporan penjualan. Mekanik bertugas menanyakan keperluan pelanggan dan menginformasikan keperluan stok ketersediaan ke bagian penjualan. Supplier bertugas menerima pesanan dari manajer, mengurus retur pembelian dan membuat nota pembelian ke pihak manajer. Pelanggan berperan sebagai konsumen yang menggunakan jasa servis atau membeli suku cadang.

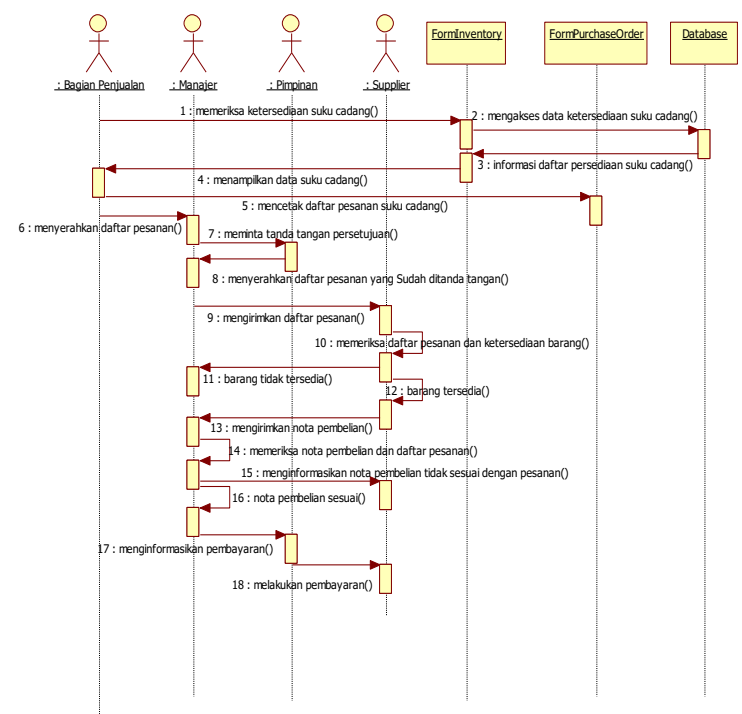

Gambar 3. Diagram Sequence Pembelian Sistem Usulan

Dari Gambar di atas, terlihat bahwa bagian penjualan melakukan pemeriksaan ketersediaan barang pada form inventory yang sudah terintegrasi dengan database. Setelah melakukan pemeriksaan ketersediaan barang, bagian penjualan mencetak daftar pesanan barang pada form purchase order dan menyerahkan daftar pesanan ke manajer. Jika 
daftar pesanan tidak disetujui maka daftar pesanan akan dikembalikan kepada bagian penjualan untuk direvisi. Selanjutnya jika pesanan sudah disetujui semua maka manajer segera melakukan pemesanan barang kepada supplier. Pihak supplier menerima daftar pesanan barang yang dipesan jika barang tidak tersedia maka pihak supplier akan melaporkan kepada manajer, jika barang tersedia maka pihak supplier akan mengirimkan nota pembelian barang sesuai dengan jenis pembelian yang dilakukan, selanjutnya manajer akan memeriksa kembali nota pembelian dari supplier dengan daftar pesanan jika nota pembelian tidak sesuai dengan daftar pesanan yang ada maka manajer akan menginformasikan kepada supplier, jika nota pembelian sesuai dengan daftar pesanan barang selanjutnya manajer akan menginformasikan pembayaran kepada pimpinan dan pimpinan akan segera melakukan pembayaran kepada supplier sebelum barang dikirimkan ke bengkel.

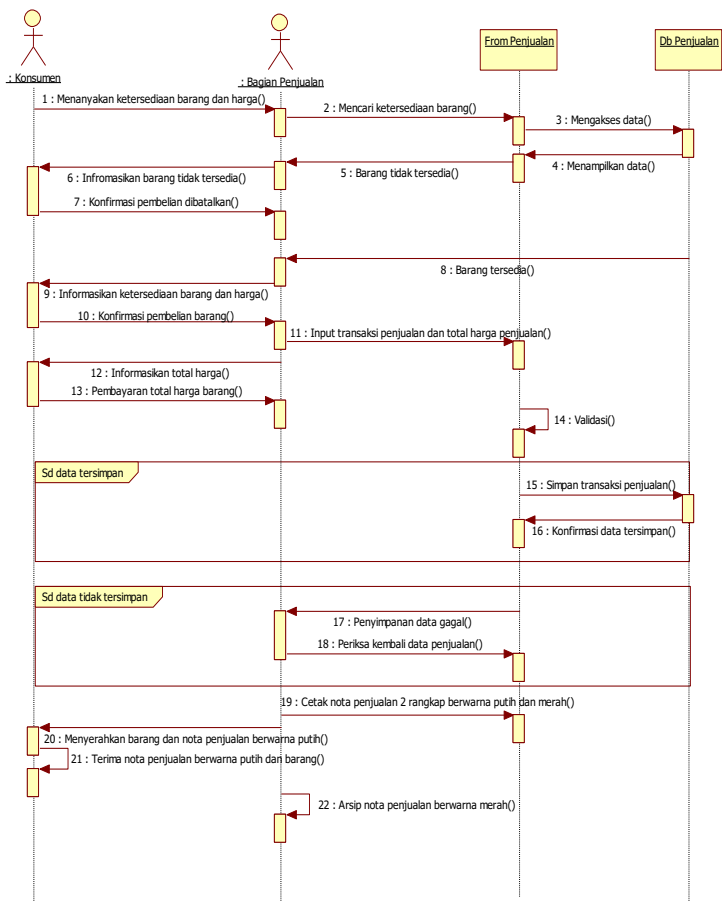

Gambar 4. Diagram Sequence Penjualan Sistem Usulan

Proses penjualan suku cadang dimulai pada saat pelanggan datang ke bengkel dan menanyakan ketersediaan barang dan harga barang kepada bagian penjualan. Bagian penjualan mencari ketersediaan barang di sistem. Jika barang tersedia maka bagian penjualan akan menginformasikan harga barang kepada konsumen, selanjutnya konsumen memberikan konfirmasi kepada bagian penjualan. Jika konsumen melakukan pembatalan pembelian maka bagian penjualan akan membatalkan. Selanjutnya jika konsumen melakukan pembelian barang maka bagian penjualan menyiapkan barang dan menginput data transaksi penjualan pada form penjualan dan menghitung total penjualan barang. Setelah bagian penjualan menginput data transaksi penjualan dan menginformasikan total harga penjualan, konsumen akan melakukan pembayaran terhadap pembelian barang dan bagian penjualan meyimpan data penjualan. Jika data penjualan sudah tersimpan maka secara otomatis akan mencetak 2 rangkap nota penjualan yang berwarna merah dan berwarna putih. Setelah konsumen membayar maka bagian penjualan akan menyerahkan barang dan nota penjualan yang berwarna putih kepada konsumen. Kemudian bagian penjualan mengarsipkan nota penjualan yang berwarna merah.

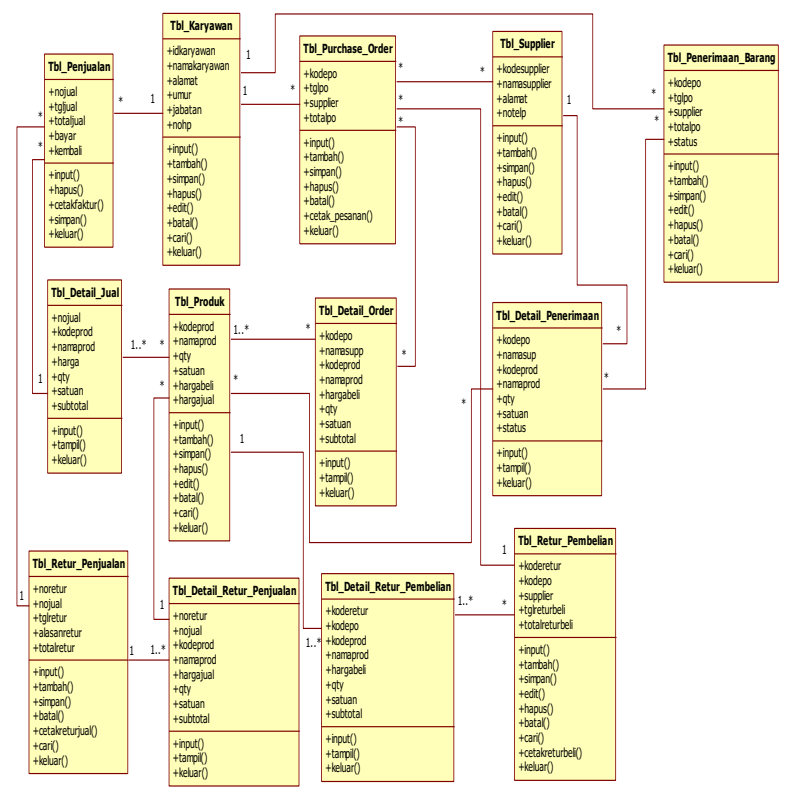

Gambar 5. Class Diagram Sistem Usulan 


\subsection{Perancangan Sistem}

Perancangan input atau layar masukan bertujuan untuk memudahkan pemakai sistem dalam proses memasukkan data. Oleh karena itu rancangan antar muka pada layar masukan harus menarik dan mudah dimengerti oleh pemakai serta tidak terlalu rumit dalam pemakaiannya. Berikut ini adalah perancangan layar masukan yang telah dirancang:

\section{Form Login}

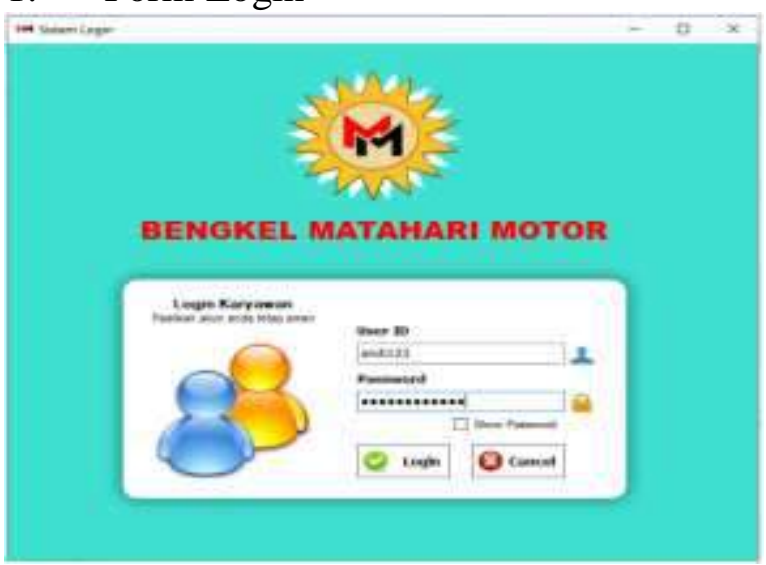

Gambar 6. Form Login

\section{Form Menu Utama}

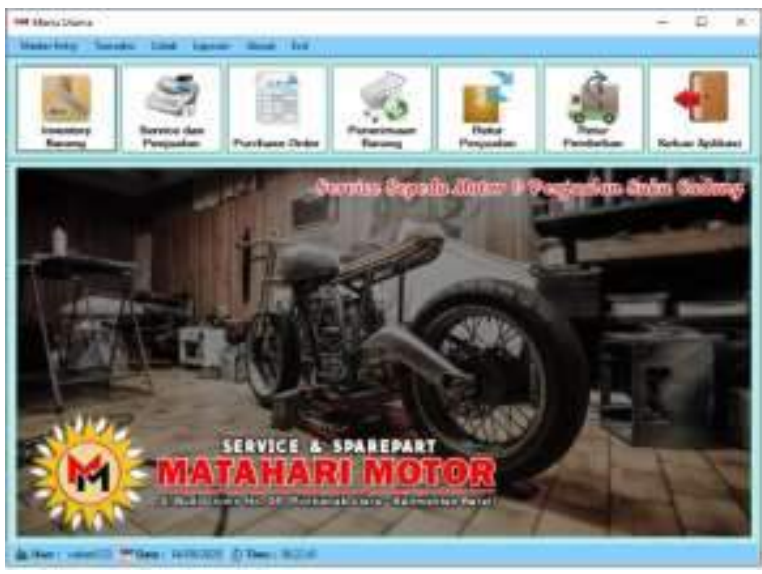

Gambar 7. Form Menu Utama

\section{Form Data Supplier}

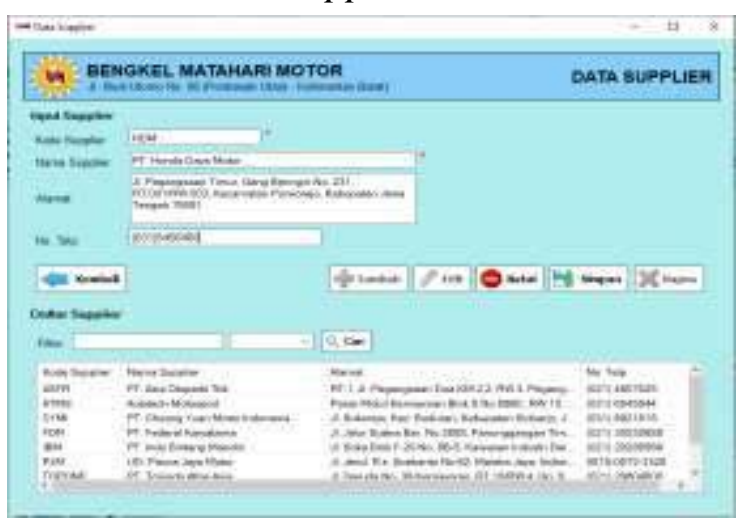

Gambar 8. Form Data Supplier

\section{Form Data Karyawan}

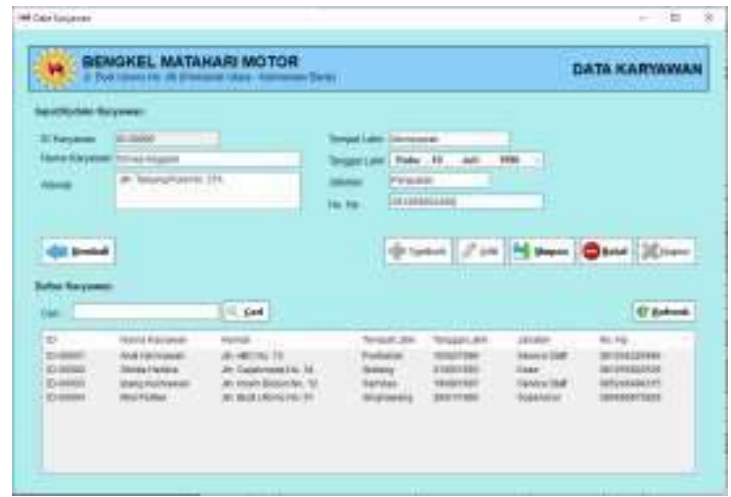

Gambar 9. Form Data Karyawan

5. Form Persediaan Suku Cadang

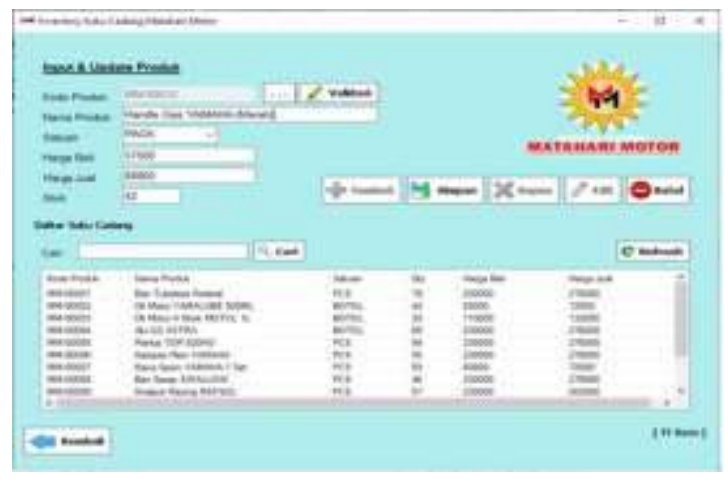

Gambar 10. Form Persediaan Suku Cadang

6. Form Penjualan

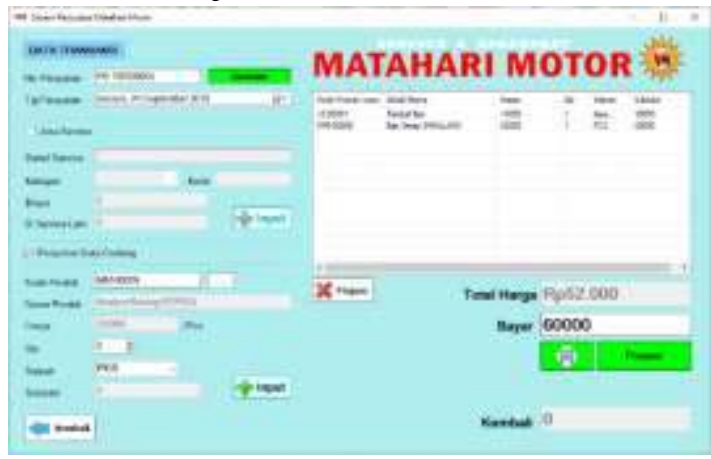

Gambar 11. Form Penjualan

\section{Form Pesanan Pembelian}

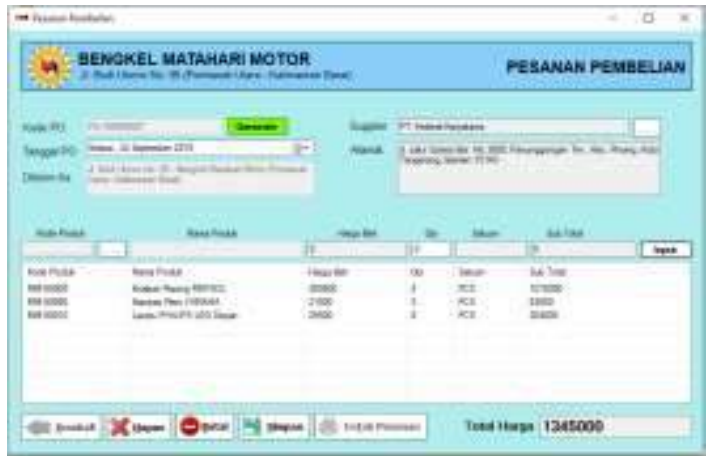

Gambar 12. Form Pesanan Pembelian 
8. Form Retur Pembelian

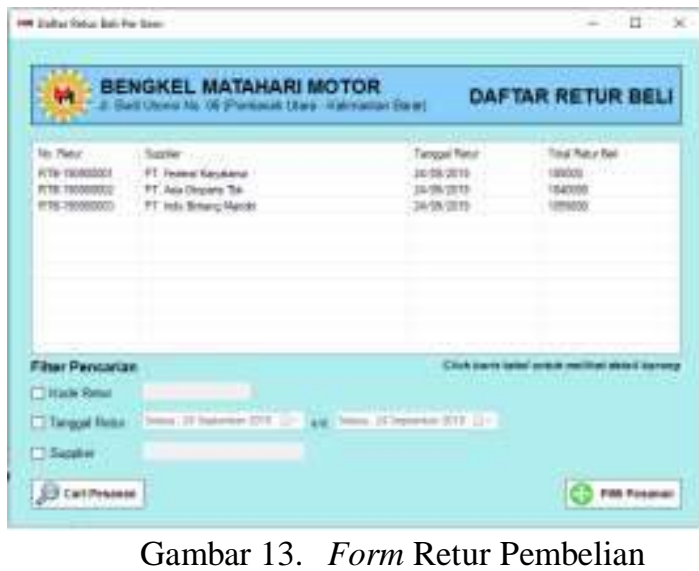

9. Form Retur Penjualan

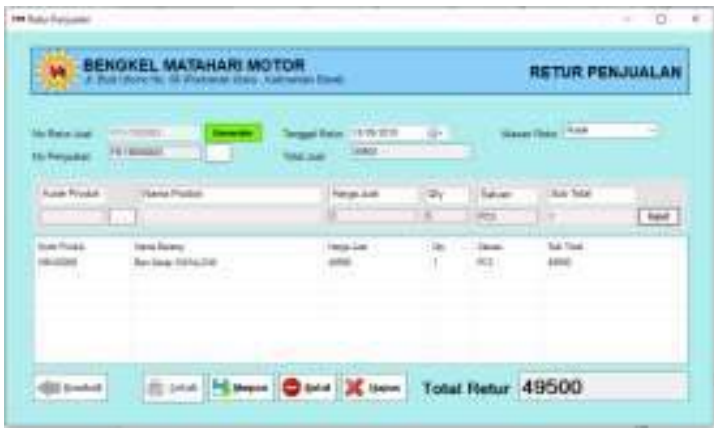

Gambar 14. Form Retur Penjualan

10. Form Cetak Laporan Persediaan

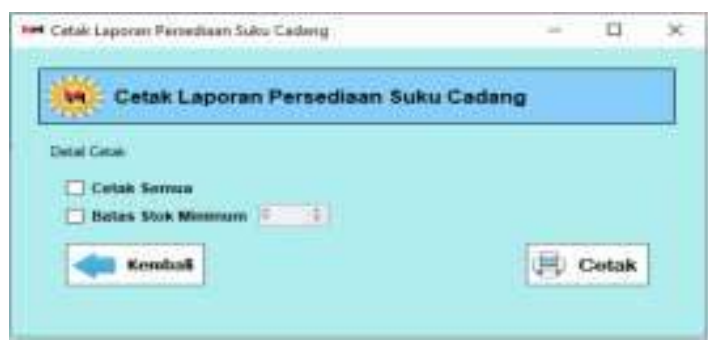

Gambar 15. Form Cetak Laporan Persediaan Suku Cadang

11. Form Cetak Laporan Penjualan

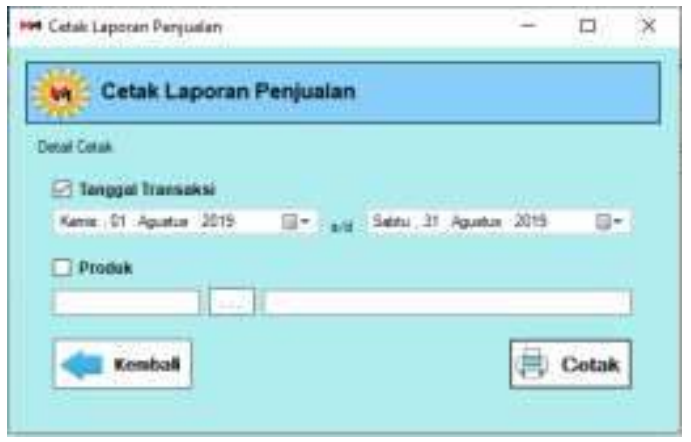

Gambar 16. Form Cetak Laporan Penjualan

\section{Kesimpulan}

Berdasarkan hasil penelitian yang telah diuraikan pada bagian sebelumnya maka dapat diambil kesimpulan sebagai berikut:

1. Sistem berjalan pada Bengkel Matahari Motor belum efektif dan efisien dalam menunjang operasional usaha karena masih bersifat manual. Secara spesifik, masalah-masalah yang muncul akibat penggunaan sistem manual adalah pengolah data persediaan, pembelian, dan penjualan yang kurang akurat dan efisien. Selain itu, penyimpanan data transaksi yang tidak rinci mengakibatkan lambatnya pelayanan servis kepada pelanggan.

2. Penerapan sistem informasi persediaan dan penjualan yang terkomputerisasi dapat mengatasi berbagai permasalahan yang dihadapi oleh perusahaan. Keuntungannya antara lain adalah kecepatan dan keakuratan dalam akses data persediaan barang, pengolahan transaksi penjualan dan pembelian sehingga meningkatkan kinerja bisnis dan menciptakan proses bisnis yang efektif dan efisien. Selain itu proses pengambilan keputusan akan terbantu dengan adanya laporan-laporan yang akurat dan terkini.

\section{Saran}

Setelah dilakukan analisis dan pengujian terhadap sistem yang dirancang, penulis memberikan beberapa saran:

1. Disarankan agar diadakan pembelajaran dan pelatihan bagi karyawan yang akan memakai sistem agar dapat mengoperasikan sistem secara optimal.

2. Untuk menghindari kehilangan data akibat hal-hal yang tidak disengaja maupun disengaja, maka diharapkan agar perusahaan selalu men-backup database sistem untuk mencegah terjadinya kerusakan sistem karena kehilangan semua simpanan data.

3. Sistem usulan yang dirancang masih memiliki kekurangan terutama proses perhitungan seperti jika adanya potongan diskon dalam jumlah transaksi yang besar. Oleh karena itu penulis mengharapkan agar sistem dapat 
dikembangkan lebih lengkap lagi apabila sistem akan dipakai untuk skala bisnis yang lebih besar.

\section{Daftar Pustaka}

[1] Indrajit, Eko Richardus dan Djokopranoto Richardus, Manajemen Persediaan. Jakarta: PT. Grasindo, 2003.

[2] Islam, S.S., Pulungan, A.H, \& Rochim, A, "Inventory Management Efficiency Analysis: A Case Study of An SME Company," Journal of Physics: Conference Series, vol.1402, no 2, 2019.

[3] Sugianti, Yuni, Analisis Dan Perancangan UML (Unified Modeling Language). Yogyakarta: Grahailmu, 2013.

[4] Ogedebe, P.M., \& Jacob, B.P, "Software Prototyping: A Strategy to Use When User Lacks Data Processing Experience," ARPN Journal of Systems and Software, vol. 2, no. 6, pp. 219-224, 2012. 